\title{
Reproductive periods of Lucina pectinata (BIVALVE; LUCINIDAE) in the Paranaguá Estuarine Complex, Paraná - Brazil
}

\author{
S. W. Christo ${ }^{a *}$, C. S. Ivachuk ${ }^{b}$ A. L. Ferreira-Júnior and T. M. Absher \\ a'Laboratório de Zoologia, Departamento de Biologia Geral, Universidade Estadual de Ponta Grossa - UEPG, \\ Campus Uvaranas, Bloco M, Av. General Carlos Cavalcanti, 4748, CEP 84030-900, Uvaranas, Ponta Grossa, PR, Brazil \\ ${ }^{b}$ Universidade Estadual de Ponta Grossa - UEPG, Ponta Grossa, PR, Brazil \\ ${ }^{\circ}$ Centro de Estudos do Mar - CEM, Universidade Federal do Paraná - UFPR, Pontal do Sul, \\ CEP 83255-000, Pontal do Paraná, PR, Brazil \\ *e-mail: wambchristo@yahoo.com.br
}

Received: July 14, 2014 - Accepted: January 20, 2015 - Distributed: May 31, 2016

(With 5 figures)

\begin{abstract}
The objectives of the present study is to describe the size for exploitation and gonadal maturation of L. pectinata in Peças Island in Paraná coast. Twenty two individuals were sampled every month, from an intertidal flat of the Peças River, Municipality of Guaraqueçaba, during two periods - summer/autumn and winter of the 2009. Environmental parameter data was obtained at the same time of the biological sampling: temperature, salinity and seawater transparency at the Peças River mouth. The animals' height, length, width, gross weight, wet weight of meat and dry weight of meat were measured at the lab. The gonad development stages (GDS), condition index (CI) and yield index (Y) were calculated. Sex identification was conducted by direct observation of the gonads and gametes under an optic microscope. Individuals were classified as males (M), females (F) or undetermined (U). The medium height observed was of $49.62 \pm 6.84 \mathrm{~mm}$. Period of more expressive gonad repletion were observed in summer when water temperature was higher. Results of GDS in both periods showed a predominance of partially filled gonad stages. This may be related with the fact that $L$. pectinata has intense gametogenesis activity, that is, the organisms do not have a resting interval, but go back to gonad restructuring rapidly after releasing the gametes. The continuity of the reproductive cycle of the specimens found in both studied periods could demonstrate a possible continuous reproduction of the species and a size for exploitation above $40.00 \mathrm{~mm}$ of height.
\end{abstract}

Keywords: reproduction, clams, Peças Island, condition index.

\section{Período reprodutivo de Lucina pectinata (BIVLAVE; LUCINIDAE) no Complexo Estuarino de Paranaguá, PR - Brasil}

\begin{abstract}
Resumo
O presente estudo tem como objetivo descrever o tamanho de exploração e a maturação gonadal de L. pectinata na Ilha das Peças no litoral do Paraná. Vinte e dois indivíduos foram amostrados mensalmente na região entre-marés no Rio das Peças, Município de Guaraqueçaba, durante 2 períodos - verão/outono e inverno de 2009. Paralelamente às amostragens, foram obtidos dados dos parâmetros ambientais: temperatura, salinidade e transparência da água do mar na foz do Rio das Peças. A altura, comprimento, largura, peso bruto, peso úmido da carne e peso seco da carne dos animais foram medidos no laboratório. Foram calculados os estágios de desenvolvimento gonadal (EDG), índices de condição (IC) e de rendimento (R). A Identificação do sexo foi realizada por observação direta das gônadas e gametas sob microscópio óptico. Os indivíduos foram classificados como: machos (M), fêmeas (F) ou indeterminados (I). A altura média observada foi de 49,62 $\pm 6,84 \mathrm{~mm}$. O período de maior repleção gonadal foi observado no verão, quando a temperatura da água foi mais elevada. Resultados dos EDG em ambos os períodos mostrou um predomínio de gônadas parcialmente cheias. Isso pode estar relacionado com o fato de que L. pectinata tem atividade gametogênese intensa, ou seja, os organismos não têm um intervalo de repouso, mas voltam a reestruturação das gônadas rapidamente após liberação dos gametas. A continuidade do ciclo reprodutivo dos espécimes encontrados em ambos os períodos estudados, pode demonstrar possível reprodução contínua da espécie e tamanho de exploração superior a 40,00 mm de altura.
\end{abstract}

Palavras-chave: reprodução, almeja, Ilha das Peças, índice de condição. 


\section{Introduction}

Lucina pectinata (Gmelin, 1791), a species popularly known in Brazil as 'almeja' or 'lambreta', is a mollusk belonging to the class Bivalvia, order Veneroida, family Lucinidae. The species is geographically distributed from North Carolina (USA) to Santa Catarina (Brazil), and is found in the muddy sediment of estuarine areas, buried at 7.0 to $30.0 \mathrm{~cm}$ deep (Nogueira and Freitas, 2002; Rios, 2009). The species is characterized as bottom infaunal organisms with no external sexual dimorphism, however, they can be identified by different-colored gonads: the females' are dark grey, whereas the males' are milky white (Araújo, 1995).

This species is one of the 40 native species of bivalve presents in the Brazilian coast that has great potential for aquaculture (Rupp et al., 2008), since the individuals reach sizes above $50 \mathrm{~mm}$ of length and with possibility to be cultivate in tide channels and mangroves. The cultivation of this species in coastal areas could be an alternative of income for the inhabitants of coastal communities (Poggio, 2002; Rondinelli and Barros, 2010). Research about the biology of L. pectinata in the Northeast of Brazil (Assis, 1985; Nogueira and Freitas, 2002), emphasize the economical interest of the species as an alternative source of income for the coastal communities (Rondinelli and Barros, 2010). In spite of the importance of the group there is still a shortage of research in the South of Brazil and the absence of works in the coast of Paraná, however stocks of this species are frequently exploited by the coastal populations.

In relationship to the individuals' size, Poggio (2002) and Delfino (2005) in Bahia's Garapuá mangrove, verified that extractive activities did not affect the population studied, since the shell length of organisms sold in the region is above $40.00 \mathrm{~mm}$, and the length at first maturity is approximately $30.00 \mathrm{~mm}$. Due to the lack of specialized work about this specie, in the coast of Paraná, one of the starting points for future programs of management and production of seeds of this species would be studies on reproductive periods.

For studies of reproductive cycle in bivalves several methods are used among these the observation of gonadal stage and condition index are very common (Christo and Absher, 2006; Silva et al., 2006; Pecharda et al., 2007). Condition index (CI) is an indirect method that supplies information related to gonadal maturation period and to suggest the period for commercialization (Baird, 1966). Associated to CI, the meat yield index (Y) can also reflect the processes of glycogenic conversion in gametes, sexual maturation, gametes elimination, nutritional state and individuals' physiological stress (Orban et al., 2004).

In this respect, temperature may be considered an important exogenous factor for reproduction control, since it is associated with a series of events that influence sexual maturation (Andrews, 1979). However, the exogenous regulation of gametogenesis is not restricted to an only factor. Salinity, especially in estuarine environment, represents an important factor in the reproductive dynamics of invertebrate animals of this environment (Cáceres-Martinez and Figueras, 1998). Food availability can also contribute to regulate reproductive processes (Bayne, 2004). In environments where temperatures rise in the beginning of spring and during summer, there is a trend towards the continuous reproduction of organisms, however with periods of more expressive gamete elimination during higher temperature months (Kreeger et al., 2003; Ren et al., 2003). The objectives of the present study is to describe the size of exploitation and gonadal maturation during two periods of the year of L. pectinata in Peças Island in Paraná coast, Brazil.

\section{Material and Methods}

For the present work, samples of L. pectinata were collected in one natural bank (with area of $100 \mathrm{~m}^{2}$ ) on an intertidal flat of the Peças River (25 $27^{\prime} \mathrm{S} ; 48^{\circ} 19^{\prime} \mathrm{W}$ ) at Peças Island, Municipality of Guaraqueçaba, Paraná (Figure 1). Due to the difficulty of obtaining individuals in other months in the studied area, sampling were made in two intervals: summer/autumn (January, February and March), and winter (June, July and August) 2009 in the spring low tide.

With the aid of local shellfish collectors and with the objective to preserve the bank of L. pectinada, twenty two individuals with commercial size (above $40.00 \mathrm{~mm}$ height), were collected manually each month digging the sediment to a depth of $50 \mathrm{~cm}$, this method is similar to the method employed by the gatherers of the region. The help of the gatherers is necessary due to the difficulty to find the natural banks of L. pectinata in the south area of Brazil.

Environmental parameter data was obtained at the same time of the sampling: temperature, salinity and seawater transparency at the Peças River mouth were obtained in order to relate a possible influence on the reproductive cycle. Temperature was measured with a mercury thermometer (precision of $0.1^{\circ} \mathrm{C}$ ), salinity through a manual refractometer (precision of 1 unit of salinity) and water transparency with a Secchi disk (extinction depth).

The animals' height $(\mathrm{H})$, length (L) and width (W) were measured at the lab. They were subsequently weighed (GW - gross weight), opened and removed from the valves for soft parts weighing (Wwm - wet weight of meat). The soft parts were then placed in an oven at $80{ }^{\circ} \mathrm{C}$ for 24 hours and then weighed for their dry weight (Dwm - dry weight of meat). The condition index (Equation 1) and meat yield index (Equation 2) were calculated according to the methodology by Lucas and Beninger (1985):

$$
\begin{aligned}
& C I=\left(\frac{D w m}{S w w}\right) * 100 \\
& Y=\left(\frac{W w m}{G w}\right) * 100
\end{aligned}
$$




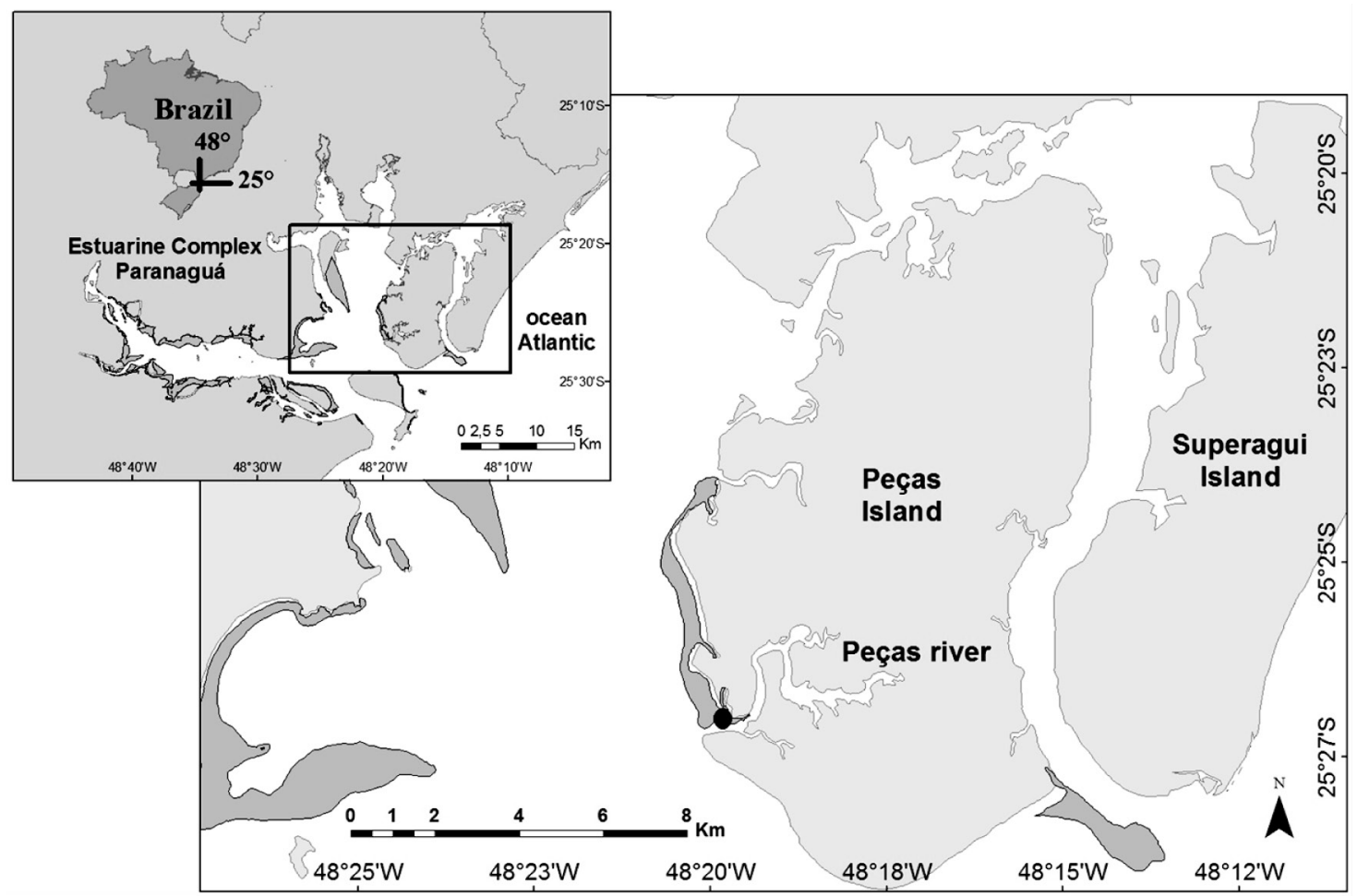

Figure 1. Location at Peças Island, Paranaguá Estuarine Complex where Lucina pectinata was collected during two periods - summer/autumn and winter 2009.

where: $Y$ : meat yield index; $W w m$ : wet weight of meat; $G w$ : gross weight; $C I$ : condition index; $D w m$ : dry weight of meat; $S w w$ : shells wet weight; $(S w w=G w-W w m)$.

Identification of sex was conducted by direct observation of the gonads (Frenkiel et al., 1997), which were scraped for observation under an optic microscope, and the individuals were classified as males $(\mathrm{M})$, females $(\mathrm{F})$ or undetermined (U). The macroscopic characterization of the individuals' gonad development stages (GDS) was based on how much of the digestive gland of either sex was covered by the gonads, considering the development stages according to Christo and Absher (2006):

- Empty (E);

- Partially empty (PE): with the gonad covering $1 / 3$ of the digestive gland;

- Partially full (PF): with the gonad covering $2 / 3$ of the digestive gland;

- Full (F) with the gonad covering the whole digestive gland;

Percentage was used to characterize GDS. After evaluation of the normality and homogeneity (Levene test) of the data, a nested ANOVA was employed to evidence differences of $\mathrm{CI}$ and $\mathrm{Y}$ (dependent variables) in the months nested in the periods (independent variables). The Student-Newman-Keuls (SNK) test was conducted in order to identify differences from one month to the other.

\section{Results}

Water temperature in the period varied between 17 and $30^{\circ} \mathrm{C}$, whereas salinity and sea water transparency varied between 21 and 24, and 0.6 and $1.2 \mathrm{~m}$, respectively, at the Peças River mouth (Figure 2).

Along the studied period's average (mean $\pm \mathrm{SD}$ ) of length, height, width and gross weight were observed. Results were for length of $51.54 \pm 6.91 \mathrm{~mm}$, heights of $49.62 \pm 6.84 \mathrm{~mm}$, widths of $26.43 \pm 4.59 \mathrm{~mm}$ and $36.70 \pm 14.93 \mathrm{~g}$ for gross weight.

Sex proportion analysis evidenced a variation between males and females of 1.76: 1 (65 males, 37 females and 30 undetermined). The gonad index showed the occurrence of more expressive gonad repletion in the first period (average of three months: F: 28.79\%, PF: 43.94\%, PE: $12.12 \%$ and E: $15.15 \%)$ compared with the second period (average of three months: F: $4.55 \%$, PF: $65.15 \%$, PE: $0.0 \%$ and E: $30.30 \%)$. Increased gonadal repletion was observed during the months of January, February and July 2009 (Figure 3).

The CI recorded during June and August 2009 were the lowest, with $2.58 \pm 0.67 \%$ and $2.52 \pm 0.38 \%$ (mean \pm SD), respectively. In contrast, an increase in CI was verified in March and July 2009, with $3.27 \pm 1.10 \%$ and $3.45 \pm 1.06 \%$ (mean $\pm \mathrm{SD}$ ), respectively (Figure 4). Statistical differences were observed among the periods $(\mathrm{DF}=1, \mathrm{~F}=3.99, \mathrm{p}<0.05)$ and the months of June and August 2009 in relation to the other months $(\mathrm{DF}=4, \mathrm{~F}=3.03, \mathrm{p}=0.02)$. The largest $\mathrm{Y}$ 


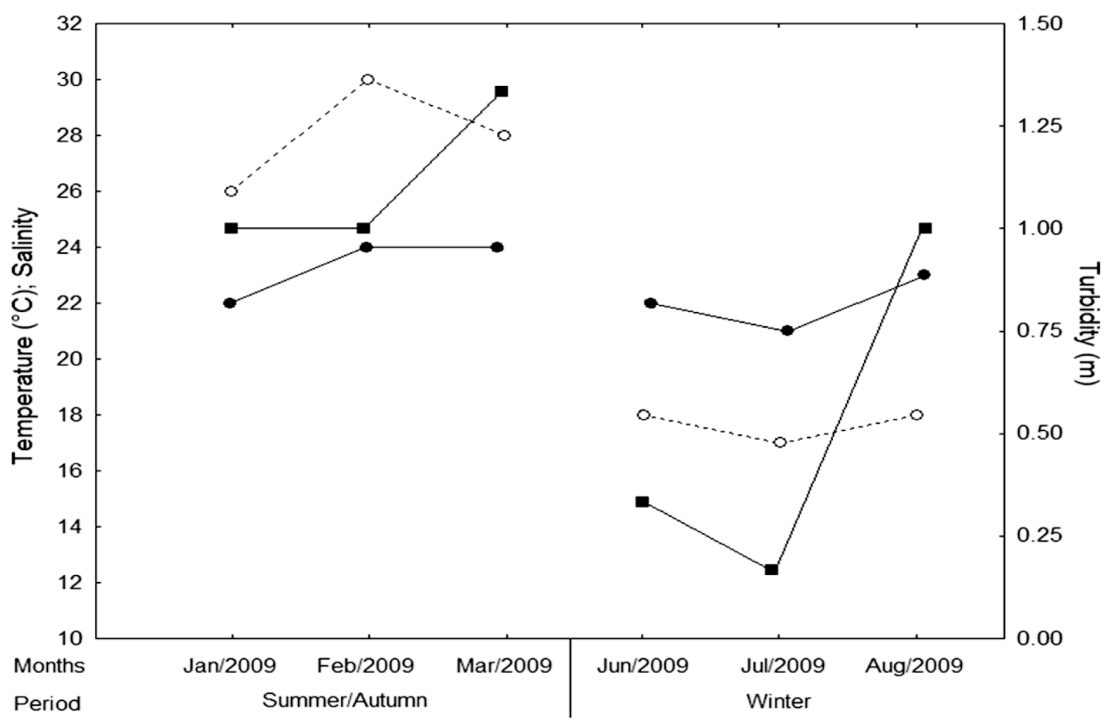

Figure 2. Variation of environmental parameters during two periods at Peças Island, Paranaguá Estuarine Complex. $\bigcirc$ : water temperature; $\bullet$ : salinity; $\mathbf{m :}$ water turbidity.

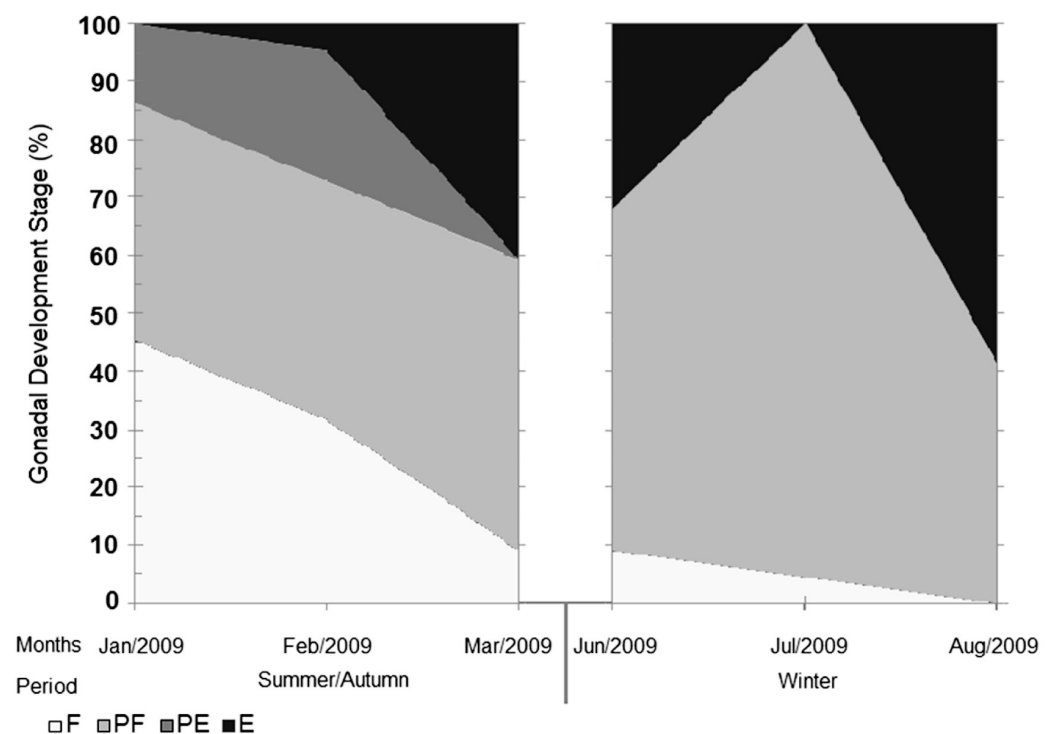

Figure 3. Change in frequency of gonadal development stage (GDS) of Lucina pectinata during two periods at Peças Island, Paranaguá Estuarine Complex. F: full, PF: partially full; PE: partially empty; E: empty.

recorded in the study was during March and July 2009, with average values of $20.95 \pm 2.93$ and $19.98 \pm 3.58 \%$ (mean $\pm \mathrm{SD}$ ), respectively (Figure 5). Statistical differences were found among the periods $(\mathrm{DF}=1, \mathrm{~F}=6.81, \mathrm{p}=0.01)$ and the months of March and June 2009 in relation to the other months ( $\mathrm{DF}=4, \mathrm{~F}=8.64, \mathrm{p}<0.0001)$.

\section{Discussion}

The observed values of length and height of L. pectinata sampled monthly at Peças Island, South of Brazil, did not differ in relation to studies conducted in the
Northeast region of Brazil (Nogueira and Freitas, 2002; Poggio, 2002; Delfino, 2005; Santana, 2010; Rondinelli and Barros, 2010). In Bahia, Delfino (2005) identified activities where 10 to 12 dozens were extracted per person during one hour's work, with an average shell length of $42.30 \mathrm{~mm}$. Another study conducted in the same region with 11,334 individuals sampled demonstrated that $73.3 \%$ had a shell length between 34 and $46 \mathrm{~mm}$, with an exploitation rate of 19.3 dozens/gatherer per day (Rondinelli and Barros, 2010). The average shell height and length of $L$. pectinata collected monthly from the Peças River 


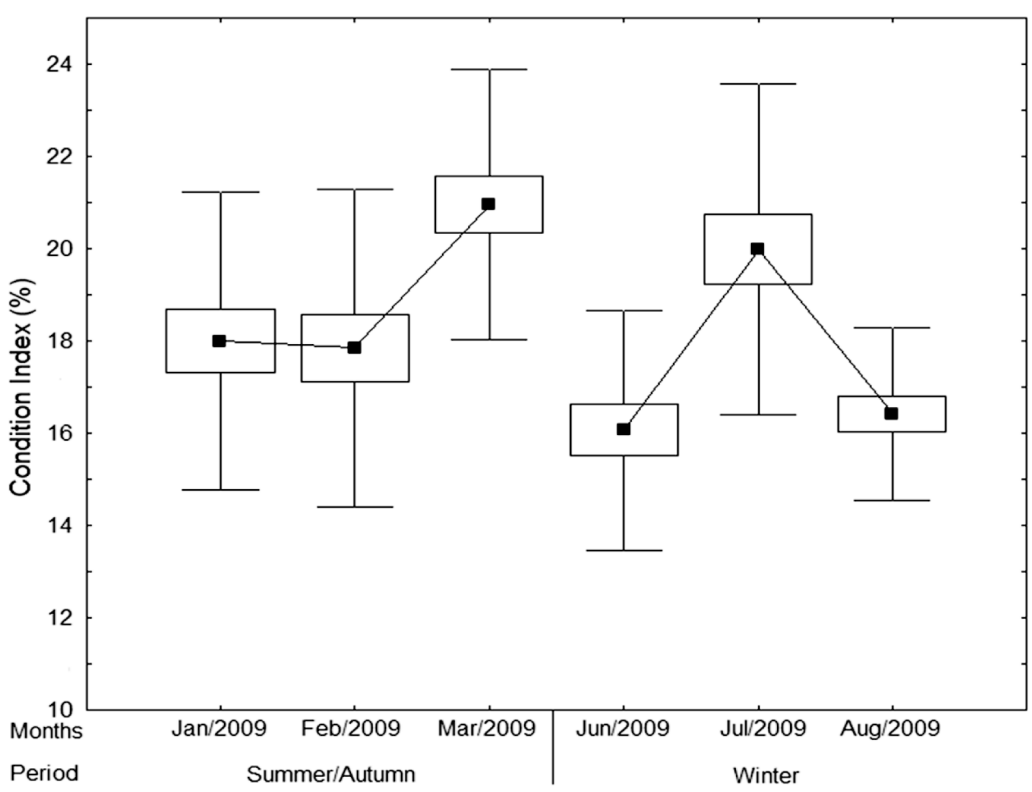

Figure 4. Variation of mean condition index (CI) of Lucina pectinata during two periods at Peças Island, Paranaguá Estuarine Complex. Student-Newman-Keuls (SNK) test indicated statistical differences $(\mathrm{p}<0.05)$ among months Mar=Jul $>$ Jan=Fev=Jun=Aug. m: mean; $\square$ : standard error; 工:standard deviation.

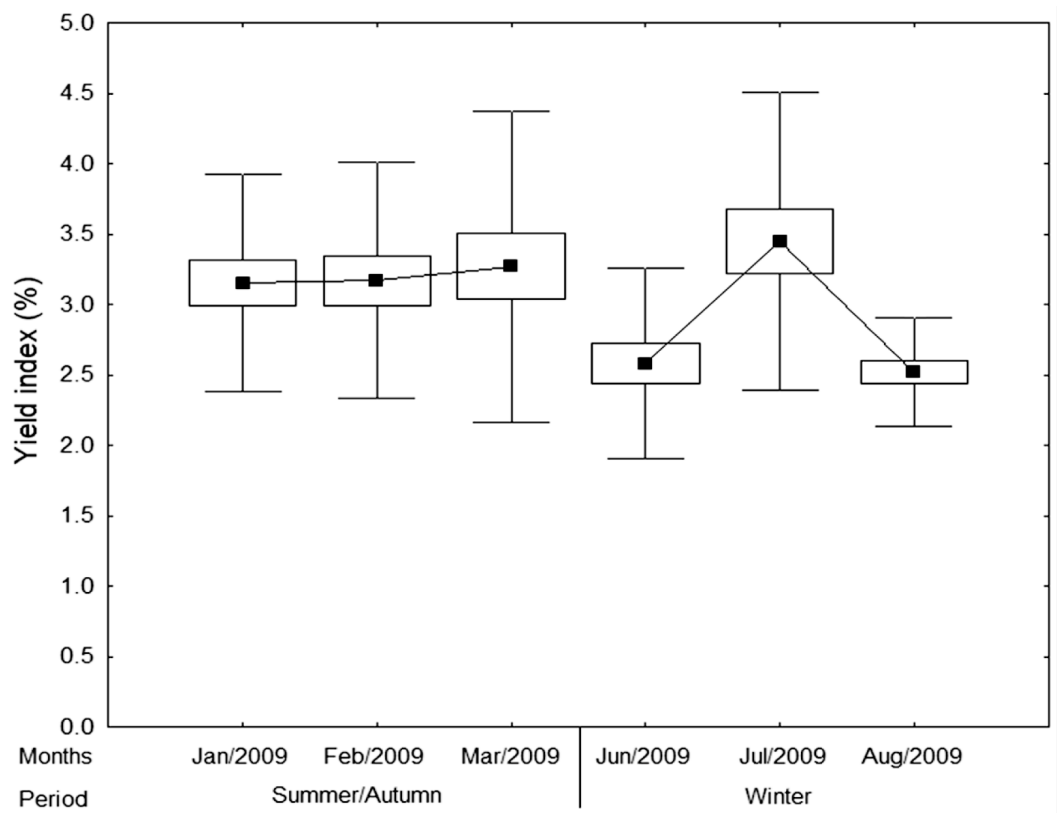

Figure 5. Variation of mean meat yield (Y) of Lucina pectinata during two periods at Peças Island, Paranaguá Estuarine Complex. Student-Newman-Keuls (SNK) test indicated statistical differences $(\mathrm{p}<0.05)$ among months Mar $=$ Jul $>$ Jan=Fev=Jun=Aug. $\mathbf{m}$ : mean; $\square$ : standard error; 工: standard deviation.

was over $40.00 \mathrm{~mm}$. However, there is no information about the rate of exploitation of this natural bank from the Peças River. The specie is commercialized in Paranaguá city - PR, where the individuals are sold with sizes above $40 \mathrm{~mm}$ of height from the extraction in the natural banks of the area of Paranaguá Estuarine Complex.
Individuals' gross weight was within an interval found in other studies in the Northeast region of Brazil (Nogueira and Freitas, 2002; Poggio, 2002; Delfino, 2005; Santana, 2010; Rondinelli and Barros, 2010). Since the animals' body weight is closely related with the gonad developmental stage, fluctuation of this variable can be 
interpreted through the association of weight with the individual's physiological condition (Kang et al., 2000; Ren et al., 2003).

The sexual proportion analysis of Lucina pectinata evidenced a ratio of 2 males: 1 female in the natural bank of Peças River. The prevalence of males in the area was observed in populations of L. pectinata in northeastern Brazil (Poggio, 2002; Delfino, 2005).

High Y values could indicate that production would be better exploited in July 2009. An average value of $19.98 \pm 3.58 \%$ was found for meat yield (Y), with elevation of the values in July of 2009, indicating that a larger maturation and better use of the production would be possible on this month of the year. Delfino (2005) found an average variation of 18.1 to $24.2 \%$ of $\mathrm{Y}$ with higher values in winter due to higher availability of food as a result of increased rainfall, may be emphasized that other months could also be appropriate for extraction of Lucina pectinata in Peças Island. This index is used in farming, where it can provide information about the best time of year to remove animals from the environment or from farming structures for subsequent commercialization. High $\mathrm{Y}$ values may suggest that $L$. pectinata is a species with potential for aquaculture, since other species produced along the Paraná coast have Y values between 15 and 40\% (Absher, 1989; Christo and Absher, 2006).

Low CI values as observed in June and August 2009 indicate that a biological effort was made, whether in maintenance energy to live in unsatisfactory environmental conditions and/or in gametes release. In contrast, high CI percentages indicate higher energy accumulated in the organisms, and a consequent increase in gonad material (Orban et al., 2004). In studies at the Ceará - Northeast of Brazil, Santana (2010) reports higher average values CI in July and November 2008, and March and July 2009. These could be related with rainier periods, however, the author used CI with no standardization of the organisms' dry meat weight, therefore reflecting in higher values than usually found for this index (Santana, 2010).

Results of GDS in both periods showed a predominance of gonads in development (PF and PE). Using this macroscopic methodology, Delfino (2005) identified a higher predominance of organisms with partially filled gonads in a mangrove in Bahia (Northeast area). According to Assis (1985) in studies in the beach of Restinga (Northeast area), this predominance of gonad material under development is related with the fact that $L$. pectinata has intense gametogenesis activity, that is, the organisms do not take a resting interval, but go back to gonad restructuring rapidly after releasing the gametes. Frenkiel et al. (1997) relates this fast gonadal restructuring of $L$. pectinata to an adaptative success of the species to inhabit mangroves and estuarine environment.

Studies conducted in Brazil's northeast where there is little seasonal variation of climate conditions show that the species has a continuous reproductive cycle along the year (Nogueira and Freitas, 2002; Poggio, 2002; Delfino, 2005; Santana, 2010). The continuous reproductive cycle of $L$. pectinata was also observed in a mangroves in Guadeloupe (Antilhas Francesas - Central America), with larger spawning intensity during the month of March and high frequency of organisms with spent gonads in the month of June (Frenkiel et al., 1997). Assis (1985) reports an increase in individual maturation during fall and spring, and higher emission of gametes in April and November for both sexes in Baia de Todos os Santos, Bahia. Periods of higher emission were also identified during spring and fall at Guarapuá mangrove in Bahia (Poggio, 2002; Delfino, 2005). The present study at the Paraná coast, suggests a gonad repletion continuity during both intervals studied using the two methodologies - macroscopic evaluation of gonad development and condition index. More expressive reproductive periods was verified in January, February and July 2009 both for GDS and CI. However, since these are indirect methods of gonadal repletion (CI and Y) they indicate a biomass increment in the soft parts of the mollusks (Baird, 1966; Orban et al., 2004). This increment can be of gonadal structuring or for the biomass of food present in the digestive gland. In order to avoid this possible mistake of the indirect methods the macroscopic gonadal stage of repletion (GDS) is used.

It is known that water temperature influences the process of maturation and release of gametes, as observed in native oysters of the genus Crassostrea (Absher, 1989; Christo and Absher, 2006) and Pteria hirundo (Salvador et al., 2011); Anomalocardia brasiliana cockle (Boehs et al., 2008; Luz and Boehs, 2011); Nodipecten nodosus scallop (Albuquerque and Ferreira, 2006; Rupp and Parsons, 2004); Perna perna mussel (Ferreira and Magalhães, 2004); Tagelus plebeius (Ceuta and Boehs, 2012) and Crassostrea gigas cultivated oyster (Manzoni and Schmitt, 1997).

One can say that the exploration size of L. pectinata bivalves in the Peças River at Peças Island is above $40.00 \mathrm{~mm}$ of shell height. With regard to the species' reproductive cycle, continuity was found in both periods studied, which could indicate possible continuous reproduction of the species, if the environmental variations observed in the region are taken into consideration. However, in order to confirm this information more studies are necessary about the species reproductive cycle and of the rate of exploration of the natural banks in the area.

\section{References}

ABSHER, T.M., 1989. Populações naturais de ostras do gênero Crassostrea do litoral do Paraná: desenvolvimento larval, recrutamento e crescimento. São Paulo: Instituto Oceanográfico, Universidade de São Paulo, 185 p. PhD Thesis.

ALBUQUERQUE, M.C.P. and FERREIRA, J.F., 2006. Eficiência comparada do cultivo da vieira Nodipecten nodosus (Linnaeus, 1758) (Bivalvia: Pectinidae) em diferentes densidades e profundidades. Biotemas, vol. 19, no. 2, pp. 37-45.

ANDREWS, J.D., 1979. Pelecypoda: Ostreidae. In: A.C. GIESE and J.S. PIERSE, eds. Reproduction of marine invertebrate. New York: Academic Press, pp. 293-341. http://dx.doi.org/10.1016/ B978-0-12-282505-7.50013-0.

ARAUJO, M.M.S., 1995. Introdução à liberação de gametas e desenvolvimento embrionário de Lucina pectinata (Gmelin, 1791) e Anomalocardia brasiliana (Gmelin, 1791), visando seu uso em 
bioensaios ecotoxicológicos. Salvador: Instituto de Biologia, Universidade Federal da Bahia, 32 p. Masters Dissertation.

ASSIS, R.C.F., 1985. Maturação sexual de Lucina pectinata (Gmelin, 1791) (Mollusca - Bivalvia). Universitas, vol. 34, pp. 77-92.

BAIRD, R.H., 1966. Factors affecting the growth and condition of mussels (Mytilus edulis). Fishery Investigations II, vol. 25, pp. 1-33.

BAYNE, B.L., 2004. Phenotypic flexibility and physiological tradeoffs in the feeding and growth of marine bivalve molluscs. Integrative and Comparative Biology, vol. 44, no. 6, pp. 425-432. http://dx.doi.org/10.1093/icb/44.6.425. PMid:21676728.

BOEHS, G., ABSHER, T.M. and CRUZ-KALED, A.C., 2008. Ecologia populacional de Anomalocardia brasiliana (GMELIN, 1791) (BIVALVIA, VENERIDAE) na Baía de Paranaguá, Paraná, Brasil. Boletim do Instituto de Pesca, vol. 34, no. 2, pp. 259-270.

CÁCERES-MARTINEZ, J. and FIGUERAS, A., 1998. Long-term survey on wild and cultured mussels (Mytilus galloprovincialis Lmk) reproductive cycles in the Ria de Vigo (NW Spain). Aquaculture, vol. 162, no. 1-2, pp. 141-156. http://dx.doi.org/10.1016/S00448486(98)00210-5

CEUTA, L.O. and BOEHS, G., 2012. Reproductive cycle of Tagelus plebeius (Mollusca: Bivalvia) in the estuary of the Cachoeira River, Ilhéus, Bahia, Brazil. Brazilian Journal of Biology = Revista Brasileira de Biologia, vol. 72, no. 3, pp. 569-576. http:// dx.doi.org/10.1590/S1519-69842012000300020. PMid:22990828.

CHRISTO, S.W. and ABSHER, T.M., 2006. Reproductive period of Crassostrea rhizophorae (GUILDING, 1828) and Crassostrea brasiliana (Lamark, 1819) (Bivalvia: ostreidae) in Guaratuba bay, Paraná, Brazil. Journal of Coastal Research, vol. 39, pp. 1215-1218.

DELFINO, A.C.S., 2005. Estudos Complementares da Dinâmica de População de Lucina pectinata (Gmelim, 1791), no Ecossistema de Manguezal de Garapuá - Cairu - Bahia. Salvador. Salvador: Universidade Federal da Bahia, 79 p. Monograph.

FERREIRA, J.F. and MAGALHAES, A.R.M., 2004. Cultivo de mexilhões. In: C.R. POLI, A.T.B. POLI, E.R. ANDREATTA and E. BELTRAME, eds. Aqüicultura: experiências brasileiras. 1st ed. Florianópolis: Multitarefa, vol. 1, pp. 221-250.

FRENKIEL, L., GROS, O. and MOUEZA, M., 1997. Storage tissue reproductive strategy in Lucina pectinata (Gmelin), a tropical lucinid bivalve adapted to a reducing sulfur-rich, mangrove enviroment. Invertebrate Reproduction \& Development, vol. 31, no. 1-3, pp. 199-210. http://dx.doi.org/10.1080/07924259.1997.9672577.

KANG, C.K., PARK, M.S., LEE, P.Y., CHOI, W.J. and LEE, W.C., 2000. Seasonal variation in condition, reproductive activity and biochemical composition of the pacific oyster Crassostrea gigas, in suspended culture in two coastal bays of Korea. Journal of Shellfish Research, vol. 19, no. 3, pp. 771-778.

KREEGER, D., THOMAS, R., HERTLER, H. and RAKSANY, D., 2003. Spatial and temporal variation in oyster fitness in San Antonio Bay, Texas, 1998-2002. Journal of Shellfish Research, vol. 22 , no. 1 , pp. 338-339.

LUCAS, A. and BENINGER, P.G., 1985. The use of physiological condition indices in marine bivalve aquaculture. Aquaculture, vol. 44, no. 3, pp. 187-200. http://dx.doi.org/10.1016/00448486(85)90243-1.

LUZ, J.R. and BOEHS, G., 2011. Reproductive cycle of Anomalocardia brasiliana (Mollusca: Bivalvia: Veneridae) in the estuary of the Cachoeira River, Ilhéus, Bahia. Brazilian Journal of Biology $=$ Revista Brasileira de Biologia, vol. 71, no. 3, pp. 679-686. http://dx.doi.org/10.1590/S1519-69842011000400012. PMid:21881791.
MANZONI, G.C. and SCHMITT, J.F., 1997. Aspectos do crescimento e da biologia reprodutiva de Crassostrea gigas (Thunberg, 1795) cultivada na enseada da Armação do Itapocoroy $\left(26^{\circ} 47^{\prime} \mathrm{S}-48^{\circ}\right.$ 36' W). In: Anais do Simpósio Brasileiro de Aquicultura, 1997, Recife. Recife: Associação Brasileira de Aquicultura, pp. 55

NOGUEIRA, E.M.S. and FREITAS, L.M., 2002. Distribuição e aspectos biológicos de Lucina pectinata (Gmelin, 1791) (Bivalvia-Lucinidae) na Lagoa Mundaú-Alagoas-Brasil. Tropical Oceanography, vol. 30, no. 1, pp. 7-14.

ORBAN, E., DI LENA, G., MASCI, M., NEVIGATO, T., CASINI, I., CAPRONI, R., GAMBELLI, L. and PELLIZZATO, M., 2004. Growth, nutricional quality and safety of oysters (Crassostrea gigas) cultured in the Lagoon of Venice (Italy). Journal of the Science of Food and Agriculture, vol. 84, no. 14, pp. 1929-1938. http://dx.doi.org/10.1002/jsfa.1896.

PECHARDA, M., ZUPAN, I., BAVCEVIC, L., FRANKIC, A. and KLANJSCEK, R., 2007. Growth and condition index of mussel Mytilus galloprovincialis in experimental integrated aquaculture. Aquaculture Research, vol. 38, pp. 171401720.

POGGIO, C.A., 2002. Biologia quantitativa de Lucina Pectinata (Gmelin, 1791) (Bivalvia-Lucinidae) no ecossistema de manguezal de Garapuá. Salvador. Salvador: Universidade Federal da Bahia, 91 p. Monograph.

REN, J.S.; ROSS, A.H. and SCHIEL, D.R., 2003. Functional descriptions of feeding and energetics of the Pacific oyster Crassotrea gigas in New Zealand. Marine Ecology Progress Series, no. 208, pp. 119-130.

RIOS, E.C., 2009. Compendium of Brazilian Sea Shell. Rio Grande: FURG. 676 p.

RONDINELLI, S.F. and BARROS, F., 2010. Evaluating shellfish gathering (Lucina pectinata) in tropical mangrove system. Journal of Sea Research, vol. 64, no. 3, pp. 401-407. http://dx.doi. org/10.1016/j.seares.2010.06.002.

RUPP, G.S. and PARSONS, G.J., 2004. Effects of salinity and temperature on a survival and byssal attachment of the lion's paw scallop Nodipecten nodosus at its southern distribution limit. Journal of Experimental Marine Biology and Ecology, vol. 309, no. 2, pp. 173-198. http://dx.doi.org/10.1016/j.jembe.2004.03.018.

RUPP, G.S., OLIVEIRA NETO, F. and GUZENSKI, J., 2008. Estado actual del cultivo de moluscos bivalvos en la región sudeste-sur de Brasil. In: A. LOVATELLI, A. FARÍAS and I. URIARTE, eds. Taller técnico regional de la FAO sobre el estado actual del cultivo y manejo de moluscos bivalvos y su proyección futura: factores que afectan su sustentabilidad en América Latina. Roma: FAO, vol. 12, pp. 77-89.

SALVADOR, G.C., ALBURQUERQUE, M.C.P.E. and FERREIRA, F., 2011. Influence of the collector type and At-Sea cultivation period on seeds recovery rate and growth out of Pteria hirundo in sulthren Brazil. Boletim do Instituto de Pesca, vol. 37, no. 4, pp. 327-340.

SANTANA, L.M.B.M., 2010. Biologia reprodutiva e considerações sobre parasitismo em Lucina pectinata (Mollusca:Bivalvia) em um estuário tropical. Fortaleza: Universidade Federal do Ceará, 83 p. Masters Dissertation.

SILVA, R.F., FERREIRA, F.M., FERREIRA, J.F. and VALDUGA, E.R., 2006. Uso da porcentagem de carne cozida como método de avaliação do índice de condição e previsão de desova, colheita e colocação de coletores para mexilhão Perna perna (Linneaus, 1758). In: Anais do Aquaciência, 2006, Bento Goncalves. Bento Goncalves. UNESP, pp. 2129. 